\title{
PENGARUH JUMLAH PERCEPATAN RESTITUSI PAJAK PERTAMBAHAN NILAI TERHADAP PENERIMAAN PAJAK PERTAMBAHAN NILAI (Studi pada Kantor Pelayanan Pajak Pratama Malang Utara)
}

\author{
Astri Warih Anjarwi ${ }^{1}$, Linda Kharisma ${ }^{2}$ \\ Taxation Department, Faculty of Administrative Science, University Brawijaya ${ }^{12}$ \\ Email: astrics19@ub.ac.id ${ }^{1}$, lindakrsm@student.ub.ac.id ${ }^{2}$
}

\begin{abstract}
The Accelerated of Value Added Tax Restitution is Indonesian government's policy to a preliminary refund of value added tax overpayment. The simplification or the acceleration of the provision of restitution is done without strict examination and long process, but by simple research. Accelerated restitution policy is given to the Taxpayer who fulfills certain requirements (certain amount of restitution as mentioned above), certain criteria (Taxpayers who comply) and they are low risk Taxable Entrepreneurs that determined by the Minister of Finance. The Acceleration of Value Added Tax restitution is expected to reduce the cost compliance because the provision of restitution is done without examination and it is hoped that this policy could increase cash flow and liquidity of the economy. The research's purpose is determine to impact the number of acceleration of value added tax restitution to the acceptance of value added tax. The type of research is explanatory research with a quantitative approach. The research's data is secondary data that obtaine from the Pratama Tax Office Malang Utara. The research's data is time series data during the periode of April 2018 - November 2019. The data analysis technique on the research is a simple regresi linier analysis. The results of this research is variable number of acceleration restitution on value added tax impact and significant for the revenue value added tax in the Pratama Tax Office Malang Utara. The value of R Square earned is 0.374 which means that the number of accelerated restitution of value added tax has an impact on the variable revenue of value added tax is $37.4 \%$.
\end{abstract}

Keywords : Number of acceleration restitution on value added tax and revenue of value added tax

\begin{abstract}
ABSTRAK
Percepatan Restitusi Pajak Pertambahan Nilai (PPN) merupakan fasilitas dari pemerintah dalam pengembalian pendahuluan kelebihan pembayaran Pajak Pertambahan Nilai. Percepatan Restitusi Pajak Pertambahan Nilai dilakukan tanpa melalui alur pemeriksaan yang sangat ketat dan proses nya lama, namun melalui penelitian sederhana. Percepatan restitusi Pajak Pertambahan Nilai ini diberikan untuk Wajib Pajak Kriteria Tertentu, Wajib Pajak berisiko rendah, dan Pengusaha Kena Pajak dengan kriteria tertentu. Hal ini diharapkan dapat mengurangi biaya kepatuhan karena proses restitusi dilakukan tanpa alur pemeriksaan dan diharapkan dapat meningkatkan cash flow dan likuiditas perekonomian. Penelitian ini bertujuan untuk mengetahui pengaruh jumlah percepatan restitusi Pajak Pertambahan Nilai terhadap penerimaan Pajak Pertambahan Nilai. Jenis penelitian ini adalah explanatory research dengan pendekatan kuantitatif. Data yang digunakan bersumber dari data sekunder yang diperoleh dari Kantor Pelayanan Pajak Pratama Malang Utara. Data yang digunakan merupakan data time series selama bulan April 2018 - November 2019. Teknik analisis data yang digunakan pada penelitian ini adalah analisis regresi linier sederhana. Hasil dari penelitian ini menunjukkan bahwa variabel Jumlah Percepatan Restitusi Pajak Pertambahan Nilai berpengaruh dan signifikan terhadap Penerimaan Pajak Pertambahan Nilai di Kantor Pelayanan Pajak Pratama Malang Utara. Nilai $R$ Square yang diperoleh yaitu sebesar 0,374 yang berarti bahwa jumlah percepatan restitusi Pajak Pertambahan Nilai mempunyai pengaruh terhadap variabel penerimaan Pajak Pertambahan Nilai sebesar 37,4\%.
\end{abstract}

Kata Kunci : Jumlah Percepatan Restitusi Pajak Pertambahan Nilai, Penerimaan Pajak Pertambahan Nilai 


\section{PENDAHULUAN}

Indonesia menersapkan pemungutan Pajak Pertambahan Nilai (PPN). PPN dikenakan atas penyerahan Barang Kena Pajak (BKP) dan atau Jasa Kena Pajak (JKP) sebesar 10\% yang harus disetor oleh Pengusaha Kena Pajak (PKP). Apabila terjadi kelebihan pajak, PKP dapat melakukan kompensasi ke Masa Pajak berikutnya ataupun dapat melakukan pengembalian kelebihan pembayaran pajak atau yang dikenal dengan restitusi. Restitusi adalah proses pengembalian kelebihan pajak dari negara kepada wajib pajak, karena jumlah kredit pajak atau jumlah pajak yang dibayar lebih besar daripada jumlah pajak yang terutang. Menurut Maulida (2018) restitusi pajak adalah permohonan pengembalian kelebihan pembayaran pajak yang dilakukan oleh wajib pajak kepada negara. Istilah restitusi pajak atau pengembalian kelebihan pembayaran pajak tercantum dalam Pasal 17 UndangUndang Nomor 6 Tahun 1983 sebagaimana telah beberapa kali diubah terakhir dengan Undang-Undang Nomor 28 tahun 2007 tentang Ketentuan Umum dan Tata Cara Perpajakan (UU KUP). Pengajuan permohonan restitusi pajak dapat dilakukan melalui restitusi biasa dan restitusi pendahuluan.

Proses restitusi biasa khususnya pada PPN dimulai dengan diajukannya permohonan oleh wajib pajak (WP) kemudian dilanjutkan dengan pemeriksaan atas permohonan pengembalian kelebihan Pajak sebagaimana dimaksud dalam Pasal 4 ayat (3) harus menerbitkan surat ketetapan pajak paling lama 1 (satu) tahun atau 12 (dua belas) bulan sejak permohonan pengembalian kelebihan pajak diterima. Proses ini dinilai lama dan rumit serta dapat membuat masyarakat mengeluhkan pelayanan Direktorat Jenderal Pajak (DJP). Ketua Dewan Pimpinan Nasional Asosiasi Pengusaha Indonesia, Hariyadi Sukamdani, dan Direktur Eksekutif Gabungan Industri Minyak Nabati Indonesia, Sahat Sinaga, menyampaikan keluhannya atas lamanya jangka waktu restitusi PPN dan seringnya pelebaran area pemeriksaan sehingga membuat Wajib Pajak tidak nyaman (Bisnis Jakarta dalam Octavia, S. et.al, 2015:2).

Oleh karena itu, pemerintah melalui Direktorat Jenderal Pajak Kementerian Keuangan memberikan fasilitas perpajakan yang dijalankan pemerintah sejak April 2018 melalui kebijakan percepatan restitusi. Kebijakan ini termuat pada PMK Nomor
39/PMK.03/2018 yang telah mengalami perubahan atau penyempurnaan pada PMK Nomor 117/PMK.03/2019 tentang Tata Cara Pengembalian Pendahuluan Kelebihan Pembayaran Pajak. Kebijakan percepatan restitusi khususnya PPN dapat diberikan lebih cepat tanpa melewati alur pemeriksaan yang sangat ketat dan melalui proses yang lama. Hal ini dilakukan untuk mendorong efisiensi administrasi perpajakan, meningkatkan tingkat kemudahan berusaha, meningkatkan kepastian hukum.

Percepatan restitusi PPN memiliki keuntungan yaitu apabila dilihat dari sudut pandang Wajib Pajak dapat membantu kelancaran arus kas (cash flow) dan menjadi tambahan modal kerja bagi Wajib Pajak dalam menjalankan bisnisnya, sehingga diharapkan dapat mendorong Wajib Pajak untuk lebih patuh dalam menjalankan kewajiban perpajakannya. Menurut Siaran Pers Kementerian Keuangan RI Nomor 17/2018, kebijakan percepatan restitusi ditujukan agar lebih banyak lagi Wajib Pajak yang dapat memanfaatkan fasilitas percepatan restitusi yang pada akhirnya akan meningkatkan kemudahan berusaha dan mengurangi beban opportunity cost akibat proses pemeriksaan restitusi yang panjang dan memakan waktu lama. Bagi pemerintah sendiri, keuntungan adanya percepatan restitusi yaitu kebijakan ini akan membebaskan sumber daya manusia yang saat ini digunakan untuk pemeriksaan restitusi sehingga dapat fokus pada upaya pengawasan atas wajib pajak dengan risiko tinggi (porsi tugas para pemeriksa pajak berkurang dan dapat dialihkan untuk tugas lainnya).

Kerugian dari adanya percepatan restitusi PPN yaitu penerimaan pajak melambat khususnya PPN dari tahun sebelumnya. Negara harus mengembalikan uang yang merupakan hak wajib pajak berdasarkan permohonan yang diajukan oleh wajib pajak. Menurut Yon Arsal selaku Direktur dan Penerimaan Pajak Direktorat Jenderal Pajak Kementerian Keuangan, rendahnya penerimaan pajak itu didasari oleh beberapa faktor, salah satunya yaitu meningkatnya restitusi pajak (mediaindonesia.com, diakses pada tanggal 26 November 2019). Berdasarkan pendapat Yon Arsal dapat ditarik kesimpulan bahwa restitusi pajak dapat memengaruhi penerimaan pajak. 
Menurut Sita (2019) tingkat permohonan restitusi pajak meningkat sebesar $47,83 \%$ pada kuartal pertama tahun 2019, sedangkan tahun 2018 sebesar 34,26\%. Permohonan restitusi terbesar pada pos pajak pertambahan nilai (PPN) dan pajak penjualan atas barang mewah (PPnBM) senilai Rp38,21 triliun atau tumbuh $46,2 \%$. Hal ini tentunya menjadi perhatian khusus terutama untuk otoritas pajak di lingkungan Direktorat Jenderal Pajak untuk menggali potensi pajak agar dapat mengejar target penerimaan pajak.

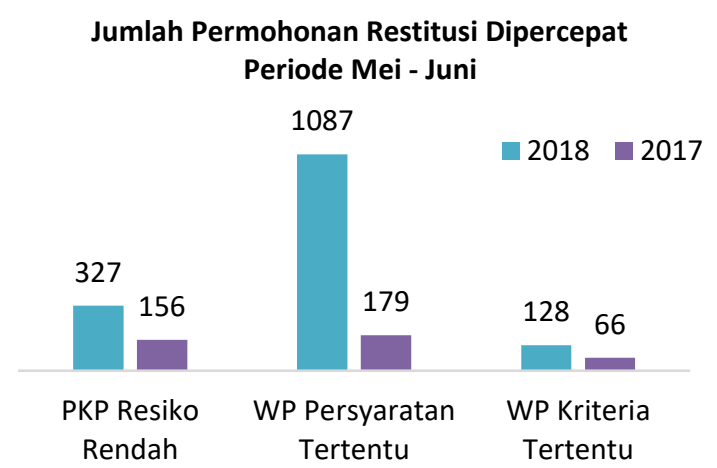

Gambar 1. Jumlah pemohon percepatan restitusi

Sumber : APBN Edisi September 2018, data diolah peneliti (2019)

Berdasarkan Gambar 1. tersebut menunjukkan bahwa untuk bulan Mei - Juni terdapat lonjakan jumlah pengajuan restitusi. Permohonan restitusi tahun 2017 dari total 401 menjadi 1.542 permohonan di tahun 2018. Artinya terjadi kenaikan hingga 284,54 persen, atau hampir empat kali lipat. Penyebab tingginya angka restitusi dikarenakan adanya Peraturan Menteri Keuangan Nomor 39/PMK.03/2018 sebagaimana telah diubah terakhir dengan Peraturan Menteri Keuangan Nomor 117/PMK.03/2019 tentang Tata Cara Pengembalian Pendahuluan Kelebihan Pembayaran Pajak, yang terbit dan efektif berlaku sejak 12 April 2018 (Kemenkeu RI, 2018). Langkah penyederhanaan ini dilakukan tanpa adanya pemeriksaan yang memakan waktu cukup lama, namun hanya melalui penelitian administratif yang sederhana untuk restitusi pendahuluan. Proses percepatan restitusi ini dilakukan dengan cepat, sehingga pemerintah harus melakukan pengembalian kelebihan pembayaran pajak lebih cepat kepada wajib pajak. Apabila proses percepatan restitusi PPN ini tidak di barengi oleh penerimaan PPN yang optimal akan berdampak pada turunnya penerimaan PPN.

Robert Pakpahan mengutarakan bahwa pada tahun 2019 penerimaan PPN tertekan dikarenakan adanya kebijakan percepatan restitusi (Setiawan dalam DDTCNews, 2019). Berdasarkan data APBN Edisi Mei 2019 menunjukkan bahwa penerimaan dari PPN atau PPnBM tercatat tumbuh negatif $4,35 \%$ persen. Faktor yang diperkirakan menekan pertumbuhan PPN atau PPnBM adalah pertumbuhan restitusi yang cukup signifikan. Banyak media nasional yang mengungkapkan bahwa menurunnya penerimaan Pajak Pertambahan Nilai disebabkan oleh adanya kebijakan percepatan restitusi yang menimbulkan lonjakan restitusi PPN.

Menurut Suryo Utomo selaku Staf Ahli Kementerian Keuangan Bidang Kepatuhan Pajak, pertumbuhan restitusi pajak yang memengaruhi realisasi penerimaan pajak bulan pertama di tahun 2019. Berdasarkan catatan Kementerian Keuangan sepanjang JanuariAgustus 2019 total pengembalian pajak atau restitusi pajak tumbuh $32 \%$. Sayangnya, pemerintah belum dapat membeberkan nominal restitusi tersebut (Santoso dalam nasional kontan, 2019).

Menurut pengamat perpajakan Danny Darussalam Tax Center (DDTC) (Redaksi DDTCNews, 2019), perlambatan penerimaan pajak pada kuartal pertama tahun 2019 seharusnya tidak perlu terlalu dikaitkan dengan restitusi PPN, alasannya restitusi merupakan konsekuensi logis dari penerapan konsep netralitas dari sistem PPN. Percepatan restitusi justru akan baik bagi kepatuhan, karena akan mengurangi distorsi atas cash flow dari wajib pajak dan efisiensi sumber daya manusia dari otoritas pajak.

Restitusi merupakan bagian dari sistem PPN yang dianut Indonesia, pada dasarnya tidak ada alasan untuk tidak mempercepat restitusi. Ketika terjadi kelebihan pembayaran pajak oleh Wajib Pajak, maka negara harus mengembalikan kelebihan tersebut karena pengembalian kelebihan pembayaran pajak merupakan hak wajib pajak, dalam hal ini kantor pelayanan pajak memiliki tugas untuk melayani Wajib Pajak, terutama terkait dengan hak-hak Wajib Pajak. Kantor pajak harus memberikan kemudahan bagi Wajib Pajak untuk mendapatkan hak-haknya termasuk hak atas restitusi. Salah satu kantor pelayanan pajak 
yang harus melakukan hal tersebut yaitu Kantor Pelayanan Pajak (KPP) Pratama Malang Utara.

Kantor Pelayanan Pajak (KPP) Pratama Malang Utara merupakan salah satu Kantor Pelayanan Pajak yang wilayah kerjanya meliputi Kecamatan Lowokwaru dan Kecamatan Blimbing. Salah satu KPP yang menerapkan Peraturan Menteri Keuangan Nomor 39/PMK.03/2018 sebagaimana telah diubah dalam Peraturan Menteri Keuangan Nomor 117/PMK.03/2019 tentang Tata Cara Pengembalian Pendahuluan Kelebihan Pembayaran Pajak yaitu Kantor Pelayanan Pajak (KPP) Pratama Malang Utara. Hal tersebut memungkinkan wajib pajak untuk mengajukan permohonan restitusi. Selain itu, realisasi pajak Kantor Pelayanan Pajak Pratama Malang Utara selama Januari-Agustus tahun 2018 dan 2019 belum mencapai target, terlihat pada tabel 1 .

Tabel 1 Realisasi Pajak Pertambahan Nilai KPP Pratama Malang Utara (dalam Jutaan Rupiah)

\begin{tabular}{|l|c|c|c|c|}
\hline $\begin{array}{c}\text { Jenis } \\
\text { Pajak }\end{array}$ & Target & $\begin{array}{c}\text { Realisasi } \\
\text { Jan-Agu }\end{array}$ & $\begin{array}{c}\text { Target } \\
\mathbf{2 0 1 8}\end{array}$ & $\begin{array}{c}\text { Realisasi } \\
\text { Jan-Agu }\end{array}$ \\
& & $\mathbf{2 0 1 9}$ & & $\mathbf{2 0 1 8}$ \\
\hline PPN & $379.475,35$ & $144.143,90$ & $303.339,10$ & $156.330,88$ \\
\hline
\end{tabular}

Sumber : KPP Pratama Malang Utara (2019)

Berdasarkan tabel diatas penerimaan PPN KPP Pratama Malang Utara bulan Januari sampai Agustus tahun 2018 sebesar Rp 156.330.880.000 dari targetnya sebesar $\mathrm{Rp}$ 303.339.103.000, sedangkan penerimaan PPN tahun 2019 sampai dengan bulan Agustus mencapai 144.143.900.000 dari targetnya sebesar 379.475.350.000. Oleh karena itu, KPP Pratama Malang Utara dituntut untuk menggali potensi pajak agar target penerimaan pajak khususnya PPN dapat tercapai, meskipun percepatan restitusi pajak diberlakukan. Berdasarkan uraian tersebut maka peneliti ingin mengetahui Pengaruh Jumlah Percepatan Restitusi Pajak Pertambahan Nilai terhadap Penerimaan Pajak Pertambahan Nilai (Studi pada Kantor Pelayanan Pajak Pratama Malang Utara).

\section{KAJIAN PUSTAKA}

Pajak Pertambahan Nilai

Pajak Pertambahan Nilai menurut Smith et.al dalam Rosdiana (2011:68) yaitu
"The VAT is a tax on the value added by a firm to its products in the course of its operation. Value added can be viewed either as the difference between a firm's sales an its purchace during an accounting period or as the sum of its wages, profit, rent, interest and other payments mot subject to the tax during that period. (Smith, et al. dalam Rosdiana, 2011:68)".

Berdasarkan pendapat tersebut dapat disimpulkan bahwa Pajak Pertambahan Nilai merupakan pajak yang dikenakan atas nilai tambah yang timbul di setiap jalur peredaran suatu barang seperti bunga, sewa, upah kerja, termasuk semua biaya untuk mendapatkan laba.

Obyek PPN yaitu setiap penyerahan Barang Kena Pajak (BKP) dan Jasa Kena Pajak (JKP) baik di dalam wilayah Indonesia maupun dari luar daerah Pabean. PPN di Indonesia dikenakan taruf sebesar $10 \%$ dari Dasar Pengenaan Pajak (DPP) seperti harga jual, nilai penggantian, nilai impor, nilai ekspor, dan nilai lainnya sebagai dasar perhitungan pajak. Prinsip PPN yaitu Prinsip Asal (PPN dipungut ditempat asal barang) dan Prinsip Tujuan (PPN dipungut di tempat barang tersebut dikonsumsi)

\section{Restitusi}

Restitusi merupakan pengembalian jumlah pembayaran pajak dari hasil perhitungan pajak terutang dengan jumlah kredit pajak menunjukkan selisih lebih atau telah dilakukan pembayaran pajak yang tidak seharusnya terutang. Tujuan adanya Restitusi yaitu untuk melindungi hak wajib pajak. Wajib pajak berhak mengajukan pengembalian kelebihan pembayaran tersebut. Penyebab adanya kelebihan pajak yaitu Pembelian BKP berupa barang modal yang dilakukan PKP mulai berproduksi sehingga belum melakukan penyerahan kena pajak; PKP memiliki kegiatan ekspor; PKP menyerahkan BKP atau JKP kepada pemungut PPN; PKP menyerahkan BKP atau JKP yang memperoleh fasilitas tidak dipungut.

\section{Percepatan Restitusi}

Kebijakan percepatan restitusi PPN adalah fasilitas dari pemerintah dalam pengembalian lebih bayar Pajak Pertambahan Nilai (PPN) yang dapat diberikan lebih cepat tanpa melewati alur pemeriksaan yang sangat ketat dan melalui proses yang lama. Fasilitas ini diatur dalam Peraturan Menteri Keuangan (PMK) Nomor 
117/PMK.03/2019 tentang Tata Cara Pengembalian Pendahuluan Kelebihan Pembayaran Pajak. Tujuan utama dari kebijakan tersebut antara lain untuk memperbaiki likuiditas Wajib Pajak, terutama eksportir. Bagi eksportir yang potensi lebih bayar PPNnya besar karena produk ekspor bebas PPN (0\%), kebijakan tersebut menjadi insentif yang dapat memacu kegiatan ekspornya. Keterangan Pers Kementerian RI No. 19/KLI/2018 mengungkapkan bahwa kebijakan percepatan restitusi diharapkan akan menurunkan cost compliance karena pemberian restitusi tanpa dilakukan pemeriksaan dan diharapkan kebijakan ini bisa meningkatkan cash flow dan likuiditas perekonomian. Syarat pengajuan percepatan restitusi PPN diatur dalam PMK Nomor 117/PMK.03/2019 atas perubahan Peraturan Menteri Keuangan (PMK) Nomor 39/PMK.03/2018. Peraturan tersebut menyebutkan bahwa wajib pajak yang dapat mendapatkan fasilitas percepatan restitusi PPN ini terbagi menjadi tiga, yaitu wajib pajak kriteria tertentu, wajib pajak persyaratan tertentu dan PKP berisiko rendah.

\section{Perbandingan Restitusi Ketentuan Lama dengan Percepatan Restitusi (Ketentuan Baru)}

Perbandingan ketentuan restitusi yang lama dan ketentuan restitusi yang baru dapat dilihat dari tabel sebagai berikut.

Tabel 2 Perbandingan Ketentuan Restitusi Biasa dan Ketentuan Restitusi yang Baru

\begin{tabular}{|c|c|c|}
\hline $\begin{array}{c}\text { Pokok } \\
\text { Pengaturan }\end{array}$ & Ketentuan Lama & Ketentuan Baru \\
\hline \multicolumn{3}{|c|}{ Wajib Pajak Krieria Tertentu } \\
\hline Subyek & 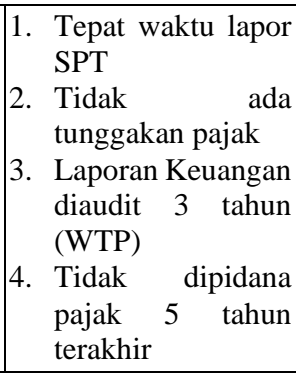 & Sama \\
\hline Penetapan & $\begin{array}{l}\text { Permohonan dan } \\
\text { Jabatan }\end{array}$ & Sama \\
\hline $\begin{array}{l}\text { Jangka waktu } \\
\text { penetapan }\end{array}$ & Berlaku 2 tahun & $\begin{array}{lr}\text { Sekali dan } & \text { berlaku } \\
\text { terus, } & \text { kecuali } \\
\text { dicabut } & \\
\text { penetapannya. }\end{array}$ \\
\hline
\end{tabular}

\begin{tabular}{|c|c|c|}
\hline $\begin{array}{c}\text { Pokok } \\
\text { Pengaturan }\end{array}$ & Ketentuan Lama & Ketentuan Baru \\
\hline Pencabutan & 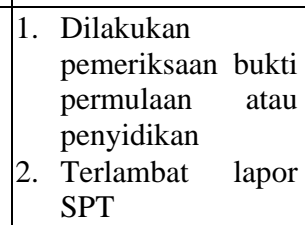 & \begin{tabular}{|l}
\multicolumn{2}{l}{ Dipidana pajak } \\
Terlambat lapor \\
SPT
\end{tabular} \\
\hline $\begin{array}{l}\text { Jangka waktu } \\
\text { pengembalian }\end{array}$ & $\begin{array}{ll}1 . & \mathrm{PPh} \rightarrow 3 \text { bulan } \\
\text { 2. } & \mathrm{PPN} \rightarrow 1 \text { bulan }\end{array}$ & Sama \\
\hline $\begin{array}{ll}\begin{array}{ll}\text { Koreksi } \\
\text { bayar }\end{array} & \text { lebih } \\
\end{array}$ & \begin{tabular}{|lr} 
SKPPKP & tidak terbit \\
dan & dilakukan \\
pemeriksaan pasal \\
17B UU KUP (Batas \\
waktu penyelesaian 1 \\
tahun)
\end{tabular} & \begin{tabular}{|lr} 
SKPPKP & terbit \\
sebesar & hasil \\
penelitian $\quad$ tanpa & \\
pemeriksaan) & \\
(Penyelesaian tetap \\
1 bulan)
\end{tabular} \\
\hline \multicolumn{3}{|c|}{ Wajib Pajak Persyaratan Tertentu } \\
\hline Subyek & $\begin{array}{l}\text { WP OP } \rightarrow \text { LB } \leq \text { Rp } 10 \\
\text { juta } \\
\text { WP Badan } \rightarrow \text { LB } \leq \text { Rp } \\
100 \text { juta } \\
\text { PKP } \rightarrow \text { LB } \leq \text { Rp } 100 \\
\text { juta }\end{array}$ & $\begin{array}{l}\text { WP OP } \rightarrow \text { LB } \leq \text { Rp } \\
100 \text { juta } \\
\text { WP Badan } \rightarrow \text { LB } \leq \\
\text { Rp 1 M } \\
\text { PKP } \rightarrow \text { LB } \leq \text { Rp 1 } \\
\text { M }\end{array}$ \\
\hline Penetapan & $\begin{array}{l}\text { Tanpa penetapan } \rightarrow \\
\text { otomatis }\end{array}$ & Sama \\
\hline $\begin{array}{l}\text { Penelitian } \\
\text { pengembalian } \\
\text { pendahuluan }\end{array}$ & 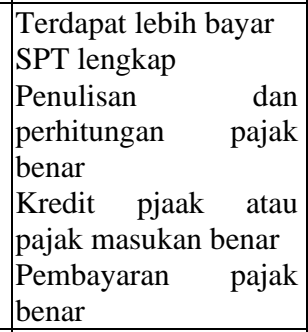 & $\begin{array}{l}\text { Sama, tetapi ebih } \\
\text { diatur tata caranya } \\
\rightarrow \quad r \text { penelitian } \\
\text { material }\end{array}$ \\
\hline $\begin{array}{l}\text { Jangka waktu } \\
\text { pengembalian }\end{array}$ & $\begin{array}{l}\mathrm{PPh} \text { OP } \rightarrow 15 \text { hari } \\
\mathrm{PPh} \text { Badan } \rightarrow 1 \text { bulan } \\
\mathrm{PPN} \rightarrow 1 \text { bulan }\end{array}$ & Sama \\
\hline $\begin{array}{ll}\text { Koreksi } & \text { lebih } \\
\text { bayar } & \end{array}$ & 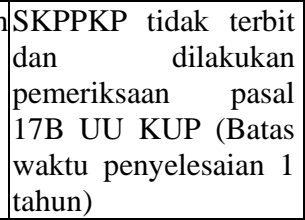 & \begin{tabular}{|lr} 
SKPPKP & terbit \\
sebesar & hasil \\
penelitian & (tanpa \\
pemeriksaan) & \\
(Penyelesaian & tetap \\
1 bulan) & \\
\end{tabular} \\
\hline \multicolumn{3}{|c|}{ Pengusaha Berisiko Rendah } \\
\hline Subyek & $\begin{array}{l}\text { Perusahaan terbuka } \\
\text { minimal saham } 40 \% \\
\text { di Bursa Efek } \\
\text { Indonesia (BEI) } \\
\text { BUMN atau BUMD } \\
\text { Produsen dengan } \\
\text { syarat tertentu }\end{array}$ & \begin{tabular}{|lr} 
Perusahaan & dengan \\
saham di Bursa \\
Efek Indonesia \\
(BEI) \\
BUMN atau BUMD \\
Produsen \\
Eksportir MITA \\
atau AEO \\
PKP Pasal 17D \\
\end{tabular} \\
\hline Penetapan & $\begin{array}{l}\text { Permohonan dan } \\
\text { jabatan }\end{array}$ & Sama \\
\hline $\begin{array}{l}\text { Jangka waktu } \\
\text { penetapan }\end{array}$ & Berlaku 2 tahun & 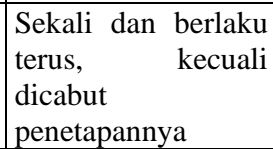 \\
\hline Pencabutan & \begin{tabular}{|l} 
Dilakukan \\
pemeriksaan bukti
\end{tabular} & \begin{tabular}{|lr}
$\begin{array}{l}\text { Diperiksa } \\
\text { permulaan } \\
\text { disidik }\end{array}$ & atau \\
\end{tabular} \\
\hline
\end{tabular}




\begin{tabular}{|l|l|l|}
\hline $\begin{array}{c}\text { Pokok } \\
\text { Pengaturan }\end{array}$ & Ketentuan Lama & Ketentuan Baru \\
\hline & $\begin{array}{l}\text { permulaan atau } \\
\text { penyidikan } \\
\text { Hasil pemeriksaan } \\
\rightarrow \text { tidak memenuhi } \\
\text { kriteria }\end{array}$ & $\begin{array}{l}\text { Dipidana pajak } \\
\text { Tidak memenuhi } \\
\text { ketentuan subyek }\end{array}$ \\
\hline $\begin{array}{l}\text { Jangka waktu } \\
\text { 1 bulan }\end{array}$ & Sama \\
\hline $\begin{array}{l}\text { Kongembalian } \\
\text { bayar lebih }\end{array}$ & $\begin{array}{l}\text { SKPPKP tidak terbit } \\
\text { dan dilakukan } \\
\text { pemeriksaan pasal } \\
\text { 17B UU KUP }\end{array}$ & $\begin{array}{l}\text { SKPPKP terbit } \\
\text { sebesar hasil } \\
\text { penelitian (tanpa } \\
\text { pemeriksaan) }\end{array}$ \\
\hline
\end{tabular}

Hipotesis

\begin{tabular}{|c|c|c|}
\hline Jumlah \\
Percepatan \\
Restitusi PPN \\
$(\mathrm{X})$
\end{tabular}$\quad \longrightarrow \begin{gathered}\text { Penerimaan Pajak } \\
\text { Pertambahan } \\
\text { Nilai (Y) }\end{gathered}$

Gambar 2. Model Hipotesis

$\mathrm{H}_{0}=$ Diduga jumlah percepatan restitusi Pajak Pertambahan Nilai (X) tidak berpengaruh terhadap penerimaan Pajak Pertambahan Nilai (Y)

$\mathrm{H}_{\mathrm{a}}=$ Diduga jumlah percepatan restitusi Pajak Pertambahan Nilai (X) berpengaruh terhadap penerimaan Pajak Pertambahan Nilai (Y)

\section{METODE PENELITIAN}

Penelitian ini merupakan penelitian penjelasan (explanatory research) dengan pendekatan kuantitatif. Penelitian dilakukan di Kantor Pelayanan Pajak Pratama Malang Utara yang berlokasi di Jalan Jaksa Agung Suprapto No.29-31 Kota Malang. Penelitian ini menggunakan data Jumlah Percepatan Restitusi PPN sebagai variabel bebas dan Penerimaan PPN sebagai variabel terikat mulai bulan April 2018-November 2019, didapat 20 populasi. Pengambilan sampel pada penelitian ini mneggunakan Nonprobability Sampling yaitu semua populasi dijadikan sampel. Model analisis dalam penelitian ini adalah regresi linier sederhana dengan menggunakan Software Aplikasi Package for Social Scienses (SPPS) Statistik 21.0. Teknik pengumpulan data yang digunakan yaitu dokumentasi dengan cara peneliti mengumpulkan, mencatat, atau mendata, serta mengkaji data yang telah didapatkan dan studi kepustakaan.

\section{HASIL DAN PEMBAHASAN}

\section{Analisis Statistik Deskriptif}

Hasil analisis statistik deskriptif adalah sebagai berikut.

Tabel 3 Hasil Analisis Statistik Deskriptif

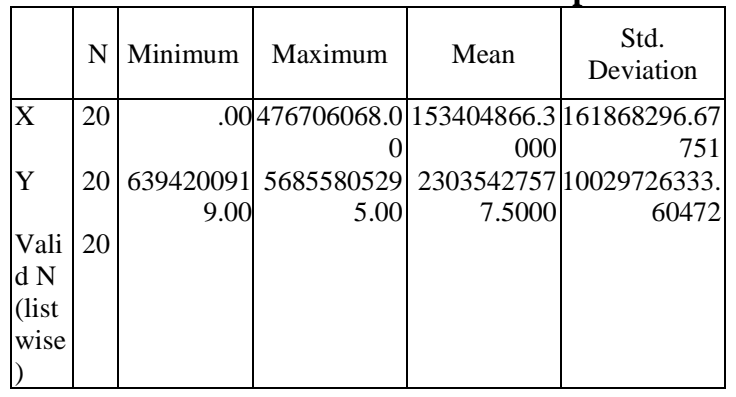

Sumber : Output SPSS 21.0, 2020

Berdasarkan Tabel 4.1 dapat dilihat bahwa variabel jumlah percepatan restitusi PPN memiliki nilai terendah sebesar 0 dan nilai tertinggi sebesar 476706068. Selain itu nilai rata-ratanya sebesar 153404866,3 dengan standar deviasi sebesar 161868296,67751. Sedangkan, variabel penerimaan PPN memiliki nilai terendah sebesar 6394200919,0 dan nilai tertinggi sebesar 56855805295.00 serta nilai rata-ratanya sebesar 23035427577,5 dengan standar deviasi 10029726333.60472.

\section{Uji Asumsi Klasik}

a. Hasil Uji Normalitas

Uji Normalitas dilakukan dengan menggunakan Kolmogorof-Smirnov, sebagai berikut.

Tabel 4 Hasil Uji Normalitas

One-Sample Kolmogorov-Smirnov Test

\begin{tabular}{|ll|r|}
\hline & & $\begin{array}{r}\text { Unstandardiz } \\
\text { ed Residual }\end{array}$ \\
\hline $\mathrm{N}$ & Mean & 20 \\
Normal &, 0000011 \\
Parameters ${ }^{\mathrm{a}, \mathrm{b}}$ & Std. Deviation & 7935475913 \\
Most Extreme & Absolute &, 235 \\
Differences & Positive &, 235 \\
Kolmogorov-Smirnov Z &,- 103 \\
\multicolumn{2}{|c|}{ Negative } & 1,053 \\
Asymp. Sig. (2-tailed) &, 218 \\
\hline
\end{tabular}

Sumber : Output SPSS 21.0, 2020

Berdasarkan tabel 4.2 tersebut diketahui bahwa nilai yang tertera pada Asymp. Sig. (2tailed) sebesar 0,218. Angka tersebut menunjukkan bahwa nilai signifikansi (Sign.) lebih besar (>) dari taraf nyata yang ditetapkan sebesar 0,05 . Hal tersebut berarti bahwa data terdistribusi normal atau telah memenuhi uji normalitas. 


\section{b. Uji Heteroskedastisitas}

Uji Heteroskedastisitas dalam penelitian ini dilakukan dengan menggunakan uji scatterplot sebagai berikut.

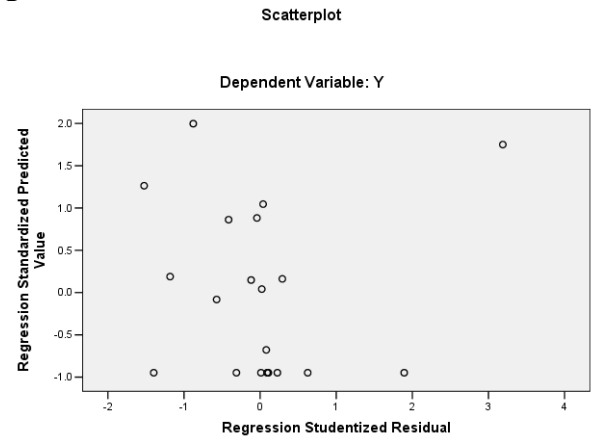

Gambar 3. Uji Heteroskedastisitas (Scatterplot) Sumber : Output SPSS 21.0, 2020

Berdasarkan Gambar 4.1 dapat diketahui bahwa data penelitian ini tidak terjadi heteroskedastisitas. Uji scatterplot tersebut menunjukkan titik-titik data tersebar di atas dan di bawah atau disekitar angka 0. Hasil uji scatterplot menyebar dan tidak membentuk pola tertentu, maka dapat disimpulkan bahwa tidak terjadi heteroskedastisitas dalam penelitian ini.

\section{c. Uji Autokorelasi}

Uji autokorelasi bertujuan untuk melihat apakah dalam model regresi linier terjadi korelasi antara suatu periode $\mathrm{t}$ dengan periode sebelumnya ( $t-1)$. Penelitian ini menggunakan uji Durbin Watson (D) dengan membandingkan nilai $\mathrm{d}_{\text {table }}$ dengan $\alpha(0,05)$. $\mathrm{D}_{\text {tabel }}$ mempunyai dua nilai batas yaitu batas atas $\left(\mathrm{d}_{\mathrm{u}}\right)$ dan batas bawah $\left(\mathrm{d}_{\mathrm{L}}\right)$. Data dikatakan $\mathrm{H}_{0}$ diterima atau tidak ada autokorelasi jika $\mathrm{d}_{\mathrm{u}}<\mathrm{d}<4-\mathrm{d}_{\mathrm{u}}$. Hasil uji autokorelasi dapat dilihat pada Tabel 5 .

Tabel 5 Hasil Uji Autokorelasi

Model Summary

\begin{tabular}{|r|r|r|r|}
\hline Model & $\mathrm{R}$ & $\begin{array}{c}\mathrm{R} \\
\text { Square }\end{array}$ & $\begin{array}{r}\text { Adjusted } \\
\text { R Square }\end{array}$ \\
\hline 1 & .612 & .374 & .339 \\
\hline
\end{tabular}

Sumber : Output SPSS 21.0, 2020

Berdasarkan Tabel IV.3 dapat diketahui bahwa nilai uji Durbin Watson (d) sebesar 1,689. Nilai $d(1,689)$ berada diantara nilai $d_{u}$ dan $4-\mathrm{d}_{\mathrm{u}}(1.411<1.689<2.589)$. Hal ini menunjukkan bahwa asumsi tidak terdapat autokorelasi telah terpenuhi.

\section{Analisis Regresi Linier Sederhana}

Uji regresi linier sederhana digunakan untuk mengukur besarnya pengaruh variabel independen yaitu Percepatan Restitusi PPN (X) terhadap variabel dependen yaitu Penerimaan PPN (Y).

a. Uji Regresi Linier

Hasil uji regresi linier sebagai berikut.

Tabel 6 Uji Regresi Linier Sederhana

\begin{tabular}{|c|c|c|c|c|c|c|}
\hline \multicolumn{7}{|c|}{ Coefficients ${ }^{a}$} \\
\hline \multirow[b]{2}{*}{ Model } & & \multicolumn{2}{|c|}{ Unstandardized Coefficients } & \multirow{2}{*}{$\begin{array}{c}\begin{array}{c}\text { Standardized } \\
\text { Coefficients }\end{array} \\
\text { Beta }\end{array}$} & \multirow[b]{2}{*}{$t$} & \multirow[b]{2}{*}{ Sig. } \\
\hline & & B & Std. Error & & & \\
\hline 1 & (Constant) & 17222328824.456 & 2542768039.84 & & 6.773 & .000 \\
\hline & $\mathrm{x}$ & 37.894 & 11.555 & .612 & 3.279 & .004 \\
\hline
\end{tabular}

Sumber : Output SPSS 21.0, 2020

Berdasarkan Tabel 5 didapatkan persamaan regresi sebagai berikut:

$$
\mathrm{Y}=17222328824.456+37,894 \mathrm{X}
$$

Hasil persamaan regresi di atas dapat diintepretasikan dengan melihat nilai konstanta sebesar 17222328824.456, nilai tersebut menunjukkan bahwa rata-rata Penerimaan PPN jika tidak ada Percepatan Restitusi PPN sebesar 17222328824.456. Sedangkan, koefisien regresi sebesar 37,894 artinya Penerimaan PPN akan meningkat sebesar Rp 37,894 untuk setiap tambahan Rp 1 untuk Percepatan Restitusi PPN $(\mathrm{X})$, maka penerimaan PPN akan meningkat sebesar Rp 37,894 dengan asumsi variabel yang lainnya dianggap konstan. Berdasarkan interpretasi di atas dapat diketahui Percepatan Restitusi PPN berpengaruh terhadap Penerimaan PPN, dengan kata lain apabila Percepatan Restitusi PPN meningkat maka akan diikuti peningkatan Penerimaan PPN.

\section{b. Koefisien Determinan $\left(\mathbf{R}^{2}\right)$}

Koefisien determinasi digunakan untuk menghitung besarnya pengaruh atau kontribusi variabel independen terhadap variabel dependen.

Tabel 7 Koefisiensi Determinasi

\begin{tabular}{|c|c|}
\hline Model & $\begin{array}{l}\text { Durbin- } \\
\text { Watson }\end{array}$ \\
\hline 1 & 1,689 \\
\hline
\end{tabular}

\section{Sumber : Output SPSS 21.0, 2020}

Berdasarkan Tabel 4.5 diperoleh hasil $\mathrm{R}^{2}$ (koefisien determinasi) sebesar 0,374, artinya $37,4 \%$ variabel penerimaan PPN akan dipengaruhi oleh variabel independen yaitu Percepatan Restitusi PPN. Sedangkan sisanya $62,6 \%$ variabel Penerimaan PPN dipengaruhi oleh variabel lain diluar model penelitian. 
Selain koefisien determinasi juga didapat koefisien korelasi yang menunjukkan besarnya hubungan antara variabel Percepatan Restitusi PPN dengan variabel Penerimaan PPN. Nilai R (koefisien korelasi) sebesar 0,612, nilai korelasi ini menunjukkan bahwa hubungan antara variabel Percepatan Restitusi PPN (X) dengan Penerimaan PPN (Y) termasuk dalam kategori kuat karena berada di selang 0,6-0,8. Hubungan antara variabel Percepatan Restitusi PPN dengan variabel Penerimaan PPN bersifat positif, artinya jika variabel independen semakin ditingkatkan maka Penerimaan PPN juga akan mengalami peningkatan.

\section{Uji Hipotesis}

Pengujian hipotesis yang telah dilakukan dalam penelitian ini yaitu menggunakan Uji t. Uji $\mathrm{t}$ yang dilakukan dalam penelitian ini dilakukan untuk mengetahui pengaruh jumlah percepatan restitusi PPN terhadap penerimaan PPN dari hasil analisis regresi signifikan atau tidak, dengan kata lain model yang diduga tepat/sesuai atau tidak. Adapun kriteria pengambilan keputusan Uji t sebagai berikut:

a. Jika nilai signifikansi $<0,05$ atau $t_{\text {hitung }}$ lebih besar dari $\mathrm{t}_{\text {tabel }}$ maka $\mathrm{H}_{0}$ ditolak dan $\mathrm{H}_{\mathrm{a}}$ diterima, artinya terdapat pengaruh signifikan antara variabel independen dengan variabel dependen.

b. Jika nilai signifikansi $>0,05$ atau $t_{\text {hitung }}$ lebih kecil dari $\mathrm{t}_{\text {tabel }}$ maka $\mathrm{H}_{0}$ diterima dan $\mathrm{H}_{\mathrm{a}}$ ditolak, artinya tidak terdapat pengaruh signifikan antara variabel independen dengan variabel dependen.

Berikut ini hasil uji t yang ditampilkan pada Tabel 8.

\section{Tabel 8 Hasil Uji t}

\begin{tabular}{|c|c|c|c|}
\hline \multicolumn{2}{|l|}{ Model } & $\mathrm{t}_{\text {hitung }}$ & $\begin{array}{c}\mathrm{t} \text { tabel }(\alpha=0,05 ; \\
\mathrm{db} \text { residual }= \\
18)\end{array}$ \\
\hline 1 & $\mathrm{X}$ & 3,279 & 2,10092 \\
\hline
\end{tabular}

a. Dependent Variable: Y

Sumber: Output SPSS 21.0, 2020

Berdasarkan Tabel IV.6 nilai $t$ hitung sebesar 3,279 . Sedangkan $\mathrm{t}_{\text {tabel }}(\alpha=0.05 ; \mathrm{db}$ residual $=$ 18) adalah sebesar 2,10092. Hal ini menunjukkan bahwa nilai pada $\mathrm{t}_{\text {hitung }}>\mathrm{t}$ tabel yaitu 3,279>2,10092 atau nilai Sig. $(0,004)<$ $\alpha=0.05$ maka model analisis regresi adalah signifikan. Hal ini berarti $\mathrm{H}_{0}$ ditolak dan $\mathrm{H}_{\mathrm{a}}$ diterima sehingga dapat disimpulkan bahwa variabel dependen (Penerimaan PPN) dapat dipengaruhi secara signifikan oleh variabel Percepatan Restitusi PPN. Berdasarkan hasil keseluruhan dapat disimpulkan bahwa variabel independen mempunyai pengaruh yang signifikan terhadap Penerimaan PPN dan dapat diketahui bahwa variabel independen tersebut memberikan pengaruh yang tinggi terhadap Penerimaan PPN.

\section{Pembahasan Hasil Penelitian}

Penelitian ini dilakukan dengan tujuan untuk mengetahui pengaruh percepatan restitusi PPN terhadap penerimaan PPN dengan menggunakan PMK 117/PMK.03/2019 sebagai acuan. Hal ini dikarenakan PMK 117/PMK.03/2019 merupakan dasar dilakukannya percepatan restitusi PPN. Menurut PMK 117/PMK.03/2019, percepatan restitusi diberikan tanpa melalui alur pemeriksaan dan proses yang lama, serta diberikan kepada wajib pajak yang memenuhi syarat pengajuan percepatan restitusi pajak. Berdasarkan PMK tersebut, wajib pajak dapat memperoleh proses restitusi PPN lebih cepat, namun tidak semua wajib pajak dapat mengajukan percepatan restitusi. Proses restitusi PPN yang lebih cepat akan mempengaruhi penerimaan PPN dikarenakan pemerintah harus lebih cepat memberikan pengembalian kepada wajib pajak.

Hasil dari penelitian ini menunjukkan bahwa jumlah percepatan restitusi PPN berpengaruh signifikan terhadap penerimaan PPN. Hal tersebut ditunjukkan oleh uji hipotesis dengan nilai t hitung sebesar 3,279, sedangkan $t$ tabel ( $\alpha$ $=0.05 ; \mathrm{db}$ residual $=18)$ adalah sebesar 2,10092. Hasil uji hipotesis ini menunjukkan bahwa nilai pada $\mathrm{t}$ hitung $>\mathrm{t}$ tabel yaitu 3,279 $>2,10092$ atau dengan melihat nilai Sig. $(0,004)$ $<\alpha=0.05$ sehingga percepatan restitusi PPN berpengaruh signifikan terhadap penerimaan PPN. Penelitian ini menunjukkan bahwa pengaruh percepatan restitusi PPN terhadap penerimaan PPN yang ada memberikan akibat dan dampak bagi pemerintah untuk menyalurkan dana pajak yang digunakan untuk pembiayaan, serta tidak tercapainya target penerimaan PPN.

Penelitian ini mendukung penelitian terdahulu yang dilakukan oleh Supit, et.al, (2014) mengenai Analisis restitusi PPN terhadap penerimaan PPN pada Kantor Pelayanan Pajak Pratama Manado, menunjukkan terdapat pengaruh antara restitusi PPN terhadap penerimaan PPN pada KPP 
Pratama Manado. Selain itu penelitian ini juga mendukung penelitian terdahulu yang dilakukan oleh Pratiwi, Elly Suryani dan Kurnia (2018) mengenai Pengaruh Self Assesment System, Surat Tagihan Pajak dan Restitusi Pajak Pertambahan Nilai Terhadap Penerimaan Pajak Pertambahan Nilai (PPN) (Studi Kasus Pada Kantor Pelayanan Pajak Pratama Cibinong Tahun 2014-2016), menunjukkan bahwa restitusi PPN berpengaruh negatif terhadap penerimaan PPN. Hal ini dapat dilihat pada hasil uji hipotesisnya yang menunjukkan bahwa thitung lebih besar dari pada ttabel $(-2,281>$ 2,037). Terdapat beberapa penelitian terdahulu yang hasilnya tidak berpengaruh seperti penelitian yang dilakukan Riftiasari (2019), Usman (2017) serta Jusmani dan Rudi (2016). Artinya penelitian ini tidak dapat mendukung dan sebaliknya penelitian ini tidak dapat didukung oleh penelitian terdahulu yang dilakukan oleh Dinar Riftiasari (2019), Sarah Usman (2017) serta Jusmani dan Rudi (2016).

\section{KESIMPULAN DAN SARAN}

\section{Kesimpulan}

Penelitian ini dilakukan untuk mengetahui pengaruh Jumlah Percepatan Restitusi PPN terhadap Penerimaan PPN. Populasi yang dipilih dalam penelitian ini adalah Wajib Pajak yang mengajukan permohonan percepatan restitusi PPN dan terdaftar di KPP Pratama Malang Utara. Berdasarkan penelitian yang dilakukan, maka dapat diambil kesimpulan bahwa jumlah percepatan restitusi PPN berpengaruh signifikan terhadap penerimaan PPN pada KPP Pratama Malang Utara. Hal ini dapat dilihat dari hasil uji hipotesis bahwa nilai pada $\mathrm{t}_{\text {hitung }}>\mathrm{t}_{\text {tabel }}$ yaitu 3,279 $>2,10092$ atau dengan melihat nilai Sig. $(0,004)<\alpha=0.05$. Maka dapat diketahui bahwa jumlah percepatan restitusi PPN merupakan salah satu faktor yang mempengaruhi penerimaan PPN. Alasanya adalah ketika wajib pajak mengajukan percepatan restitusi PPN akan terjadi pengembalian dana oleh pemerintah kepada Wajib Pajak yang melakukan percepatan restitusi PPN.

Berdasarkan kesimpulan tersebut, peneliti memberikan saran sebagai berikut:

1. KPP Pratama Malang Utara

a. Dalam hal menanggapi terjadinya percepatan restitusi PPN perlu adanya pengawasan yang lebih terhadap Wajib Pajak dalam proses pelaporan pajak, agar persentase terjadunya percepatan restitusi dapat berkurang.

b. Dalam hal penerimaan PPN, KPP Pratama Malang Utara diharapkan dapat meningkatkan potensi penerimaan PPN melalui pengawasan terhadap Wajib Pajak/Pengusaha Kena Pajak agar patuh membayar pajak khususnya PPN. Selain itu, melakukan evaluasi kebijakan percepatan restitusi PPN, sehingga dapat lebih bijak dalam mengambil keputusan demi tercapainya penerimaan dari sektor perpajakan khususnya Pajak Pertambahan Nilai secara optimal.

\section{Saran}

a. Peneliti selanjutnya diharapkan dapat menambah variabel bebas lainnya dengan tujuan untuk mengetahui varibelvariabel bebas yang lain, sehingga dapat diketahui variabel bebas mana yang memperkuat dan memperlemah variabel terikat.

b. Peneliti selanjutnya diharapkan dapat memperluas obyek penelitian misalnya penelitian dilakukan pada Kantor Wilayah Direktorat Jenderal Pajak Jawa Timur III yang menampung 14 KPP Pratama dan juga lebih memperluas periode obyek penelitian, sehingga diketahui di lokasi penelitian manakah yang terjadi permasalahan dibidang PPN yang mengakibatkan target penerimaan PPN tidak tercapai.

\section{DAFTAR PUSTAKA}

Maulida, R. (2018). Restitusi Pajak: Pengertian, Tujuan dan Syarat Percepatan Restitusi Pajak. Online Pajak [on-line]. Diakses 26 Oktober 2019 dari https://www. onlinepajak.com/tentang-kami.

Ortax, Tim Redaksi. (2017). Susunan dalam Satu Naskah $10 \quad$ (Sepuluh) UndangUndang Perpajakan (5th ed.). Jakarta: Observation \& Research of Taxation (Ortax).

Octavia, S., Y. Mayowan dan S. Karjo. (2015). Analisis Proses Restitusi Pajak Pertambahan Nilai (PPN) di Indonesia (Studi Pada PT. XYZ). Jurnal Perpajakan (JEJAK), 7(1) : 1. 
Avisena, M.I.R. (2019). Restitusi Meningkat, Penerimaan Pajak Loyo. Media Indonesia [on-line]. Diakses 26 November 2019 dari https://mediaindonesia.com/read/ detail/273673-restitusimeningkatpenerimaan-pajak-loyo.

Kementerian Keuangan Republik Indonesia. (2018). APBN Kita Kinerja dan Fakta Edisi September 2018. K emenkeu [online]. Diakses 19 September 2019 dari https://www.kemenkeu.go.id/ media/10576/apbn-kitaedisiseptember-2018. pdf.

. (2019). APBN Kita Kinerja dan Fakta Edisi Mei 2019. Kemenkeu [online]. Diakses 20 September 2019 dari https://www.kemenkeu.go.id/media/ 12483/apbn-kita-mei-2019.pdf.

Santoso, Y.I. (2019). Kenaikan Restitusi Berpotensi Mengancam Penerimaan Pajak. Kontan [on-line]. Diakses 28 November 2019 dari https://nasional.kontan.co.id/news/ken aikan-restitusi-berpotensimengancampenerimaan-pajak.

Setiawan, D.A. (2019). Dirjen Pajak Paparkan 3 Faktor Target 2019 Tidak Bisa Dicapai. DDTCNews [on-line]. Diakses 20 September $2019 \quad$ dari https://news.ddtc.co.id/dirjen-pajakpaparkan-3-faktor-target-2019tidakbisa-dicapai-16418.

Rosdiana, H., E.S. Irianto, dan T.M. Putranti. (2011). Teori Pajak Pertambahan Nilai:Kebijakan dan Implementasinya di Indonesia. Bogor : Penerbit Galia Indonesia.

Kementerian Keuangan Republik Indonesia. (2018). Sukseskan Tingkat Kemudahan Berusaha, Kemenkeu Luncurkan Berbagai Fasilitas Fiskal. Dalam Keterangan Pers. Jakarta: DJP Kementerian Keuangan RI.

Jusmani dan R. Qurniawan. (2016). Pengaruh Restitusi Pajak Pertambahan Nilai Terhadap Penerimaan Pajak Pertambahan Nilai Pada Kantor Pelayanan Pajak Pratama Palembang Ilir Barat. Jurnal Media Wahana Ekonomika, 13(3) : 130-142.
Octavia, S., Y. Mayowan dan S. Karjo. (2015). Analisis Proses Restitusi Pajak Pertambahan Nilai (PPN) di Indonesia (Studi Pada PT. XYZ). Jurnal Perpajakan (JEJAK), 7(1) : 1.

Pratiwi, S.A., E. Suryani, dan Kurnia. (2018). Pengaruh Self Assesment System, Surat Tagihan Pajak dan Restitusi Pajak Pertambahan Nilai Terhadap Penerimaan Pajak Pertambahan Nilai (PPN) (Studi Kasus Pada Kantor Pelayanan Pajak Pratama Cibinong Tahun 2014-2016). Jurnal Akuntansi Bisnis dan Ekonomi, 4(2) : 1201-1210.

Usman, S. (2017). Restitution and Restitution Examination Managerial Process KPPN Value Added Tax in Manokwari. Jurnal Nusamba, 2(1) : 57-67.

Riftiasari, D. (2019). Pengaruh Restitusi Kelebihan Pembayaran Pajak Pertambahan Nilai Pada Kantor Pelayanan Pajak Pratama Jakarta Penjaringan. Moneter, 6(1) : 63-68.

Supit, W.M., D.P. Elia, dan H. Sabijono. (2014). Analisis Restitusi Pajak Pertambahan Nilai Terhadap Penerimaan Pajak Pertambahan Nilai pada Kantor Pelayanan Pajak Pratama Manado. Jurnal EMBA, 2(3) : 159-166.

DDTC. Peraturan Menteri Keuangan Nomor 39 Tahun 2018 (2018). DDTC [online]. Diakses 19 September 2019 dari https://engine.ddtc.co.id/peraturanpaja $\mathrm{k} / \mathrm{read} /$ peraturan-menteri-keuangan39pmk-032018.

Peraturan Menteri Keuangan Nomor 117 Tahun 2019 (2019, Agustus). Pajak [online]. Diakses 19 September 2019 dari http://pajak.go.id/sites/default/files/201 9-08/117PMK032019.pdf. 